\title{
PREVALENCE OF THE PRECORE G1896A MUTATION IN CHINESE PATIENTS WITH E ANTIGEN NEGATIVE HEPATITIS B VIRUS INFECTION AND ITS RELATIONSHIP TO PRE-S1 ANTIGEN
}

\author{
Jing Zhang ${ }^{1}$; Wei-Jia Xu ${ }^{1}$; Qing Wang ${ }^{1}$; Yong Zhang ${ }^{2}$; Ming Shi ${ }^{2 *}$ \\ ${ }^{1}$ Department of Clinical Laboratory, Dalian Central Hospital, Dalian 116033, Liaoning Province, China; ${ }^{2}$ Central Laboratory, \\ No.6 Hospital of Dalian, 116001, Liaoning Privince, China.
}

Submitted: September 17, 2008; Returned to authors for corrections: November 06, 2008; Approved: May 15, 2009.

\begin{abstract}
This study investigated the prevalence of the precore G1896A mutation in Chinese patients with hepatitis $\mathrm{B}$ e antigen ( $\mathrm{HBe} \mathrm{Ag})$ negative $\mathrm{HBV}$ infection and its relation to serum HBV pre-S1 antigen. The overall prevalence of the precore G1896A mutation was $72.6 \%$ in HBeAg-negative Chinese patients with detectable serum HBV DNA. The prevalence of the precore G1896A is significantly higher in Chinese HBeAg-negative patients with chronic hepatitis B than that in inactive HBV carriers with detectable serum HBV DNA. Serum pre-S1 and the precore G1896A mutation were simultaneously detected in most of Chinese HBeAg-negative patients.
\end{abstract}

Key words: Hepatitis B virus, precore mutation, pre-S1

Hepatitis B virus (HBV) infection is a global public health problem, with more than 350 million individuals chronically infected $(18,20)$. The manifestations of HBV infection ranges from the asymptomatic carrier state to chronic hepatitis B, liver cirrhosis, and hepatocellular carcinoma (18). During the initial phase of chronic HBV infection, serum HBV DNA levels are high and Hepatitis B e antigen ( $\mathrm{HBeAg})$ is present. The majority of carriers eventually loses $\mathrm{HBeAg}$ and develop antibody to $\mathrm{HBeAg}$ (anti-HBe). Seroconversion of $\mathrm{HBeAg}$, whether spontaneous or after antiviral therapy, reduces the risk of hepatic decompensation and improve survival (21). However, a portion of patients after $\mathrm{HBeAg}$ seroconversion are in the state of $\mathrm{HBeAg-negative} \mathrm{chronic} \mathrm{hepatitis} \mathrm{B.} \mathrm{These} \mathrm{patients}$ are more likely to have reactivation of HBV replication and exacerbations of hepatitis; thus, serial testing is necessary to determine if an $\mathrm{HBsAg}$-positive, $\mathrm{HBeAg}$-negative carrier is truly in the inactive state $(13,19,21)$. Sensitive PCR assays are commonly employed in such serial tests. However, these assays are often expensive and time consuming. Simple and cost effective assays are needed for distinguishing HBeAgnegative hepatitis B from the inactive HBsAg carrier state.

In most instances, $\mathrm{HBeAg-negative} \mathrm{chronic} \mathrm{hepatitis} \mathrm{B} \mathrm{is}$ a result of $\mathrm{HBV}$ variants in the precore or core promoter region. The $\mathrm{HBeAg}$ is encoded by the core gene, which is divided into the precore (PC) region and the core region by two in-frame initiating ATG codons. Transcription of these open reading frames produces the pregenomic RNA that is essential for HBV replication and the PC RNA that translates into $\mathrm{HBeAg}$, which is secreted into the serum (22). Variations

*Corresponding Author. Mailing address: Central Laboratory, No.6 Hospital of Dalian, 1 Chunhai Street, Dalian 116001, Liaoning Province, China.; Tel.: +86411 82714773; Fax: +86-411-82714773.; Email: zhsh6655@sohu.com 
in the PC region affect $\mathrm{HBeAg}$ synthesis without appreciably affecting HBV replication. The PC mutants and the basal core promoter (BCP) mutants are two major types of HBV core gene variations frequently occur that affect the synthesis of $\mathrm{HBeAg}$ (1). The most prevalent PC mutation is the 1896 guanine (G)-to-adenine (A) mutation, which creates a TAG stop codon in the PC open reading frame and abolishes $\mathrm{HBeAg}$ synthesis at the translational level (1). Most $\mathrm{HBeAg}$ negative carriers with high levels of serum HBV DNA have precore variants (4), and all the cases of transmission from $\mathrm{HBeAg}$ negative health care workers to patients and from $\mathrm{HBeAg}$ negative mothers to their babies have involved in precore mutants $(12,29)$.

Serum pre-S1 antigen reflects active viral replication in chronic HBV infection (17), and almost all symptomatic anti$\mathrm{HBe}$ patients carry pre-S1 antigen (8). The presence of preS1 antigen appears to correspond with the presence of HBV DNA, indicating hepatitis B virus replication (30). In the present study, we investigated the prevalence of precore mutation in Chinese patients with $\mathrm{HBeAg-negative} \mathrm{HBV}$ infection using a molecular-beacon assay (31), and its relationship to serum pre-S1 antigen.

From 2003 to 2007, 496 patients attending Dalian Central Hospital and Dalian No. 6 Hospital (a hospital for infectious diseases) were recruited into this study. Patients were all HBsAg positive for at least six months and $\mathrm{HBeAg}$ negative at presentation. Patients were excluded from the study if they had any of the following conditions: 1) treatment for HBV infection previously, 2) co-infection with hepatitis A, C, D and E virus or HIV, 3) a history of alcohol or drug abuse, and 4) other possible causes of chronic liver damage. In the present study, the inactive state was defined as: 1) HBsAg positive for at least six months, 2) serum HBV DNA < 10000 copies $/ \mathrm{ml}$, and 3) persistently normal ALT/AST levels (21). For patients with serum HBV DNA > 10000 copies/ml and persistently normal ALT/AST levels, liver biopsy was performed to confirm whether they are chronic hepatitis B or inactive carriers. Of the 496 patients, 296 were chronic hepatitis B patients and 200 were inactive HBV carriers. Among the inactive HBV carriers, 192 had serum HBV DNA levels below 10000 copies/ml and ALT levels below the upper limit of normal (ULN). The ULN was set as $30 \mathrm{IU} / \mathrm{L}$. Eight patients that had serum HBV DNA levels above 10000 copies/ml but ALT levels under $1 \times \mathrm{ULN}$ were confirmed by liver biopsy and had no necroinflammation in the liver. In addition, four patients with serum HBV DNA levels above 10000 copies/ml but persistent normal ALT levels were confirmed by biopsy and had moderate necroinflammation in the liver, and these patients were considered to be chronic hepatitis B. The demographic data, HBV DNA levels and liver biochemistry of the $496 \mathrm{HBeAg-negative} \mathrm{patients} \mathrm{were} \mathrm{summarized} \mathrm{in}$ Table 1. Serum samples were collected and stored at $-70^{\circ} \mathrm{C}$ until use.

Table 1. Demographic data for the study population on presentation

\begin{tabular}{ll}
\hline Number of patients & 496 \\
Male: female ratio & $388: 108$ \\
Median age, years (range) & $43(27-56)$ \\
HBeAg+ (\%) & 0 \\
Anti-HBe+ (\%) & 100 \\
ALT levels (Mean $\pm \mathrm{SD}, \mathrm{IU} / \mathrm{L})$ & $65.8 \pm 60.1$ \\
HBV DNA (Median, $\log _{10}$ copies/mL) & 4.56 (undetectable to 8.77) \\
Chronic hepatitis: inactive carrier & $296: 200$ \\
\hline
\end{tabular}


Hepatitis B surface antigen (HBsAg), hepatitis B surface antibody (HBsAb), $\mathrm{HBeAg}$, anti-HBe and hepatitis B core antibody (anti-HBc) were measured with commercially available reagents (Kehua Biotech, Shanghai, China) according to manufacturer's instruction. Alanine aminotransferase (ALT) activity was determined kinetically on Hitachi 7600 automatic biochemistry analyzer with commercial kits (Roche Diagnostics, Penzberg, Germany). HBV DNA levels were tested using real-time PCR reagents (Fosun Diagnostics, Shanghai, China) on ABI Prism 7500 PCR System (Applied Biosystems Inc, Foster City, CA). All reagents were approved by State Food and Drug Administration of China for in vitro diagnostic use.

The G1896A precore mutation was detected by a molecular-beacon assay described by Wartz et al (31). In brief, two molecular beacons containing the wild-type G1896 and mutant A1896 sequences were constructed to hybridize to their targets within a 104-bp fragment that was amplified by the PB primers. HBV DNA was extracted from $200 \mu 1$ of serum with a QIAamp DNA mini kit (Qiagen, Chatsworth, CA, USA) and eluted in $50 \mu 1$ of elution buffer. The reaction was carried out in a final volume of $25 \mu \mathrm{l}$ of PCR consisting of PCR mix, $0.25 \mu \mathrm{mol}$ of TET wild-type molecular beacon, $0.25 \mu \mathrm{mol}$ of FAM mutant molecular beacon, and $5 \mathrm{ng}$ of HBV DNA. The amplification was performed on ABI Prism 7500 (Applied Biosystems, Foster City, CA, USA) with the procedure consisting of $95^{\circ} \mathrm{C}$ for $10 \mathrm{~min}$ followed by 40 cycles of $95^{\circ} \mathrm{C}$ for $20 \mathrm{~s}, 62^{\circ} \mathrm{C}$ for $30 \mathrm{~s}$, and $72^{\circ} \mathrm{C}$ for $30 \mathrm{~s}$. The fluorescence spectra of the molecular beacons were detected measured during the annealing step of the PCR cycle.

Serum pre-S1 antigen was measured with commercially available enzyme immunoassay (EIA) kits (Fosun Diagnostics, Shanghai, China) according to manufacturer's instruction. In brief, microtiter plates with 48 wells were coated with monoclonal antibodies. For the test, $200 \mu \mathrm{l}$ of serum samples or controls were added into each well and incubated at $37^{\circ} \mathrm{C}$ for $30 \mathrm{~min}$. Then the wells were empted and washed three times before adding peroxidase-conjugated monoclonal antibody in to the wells. After incubated at $37^{\circ} \mathrm{C}$ for another $30 \mathrm{~min}$, enzyme reaction was performed by adding the substrates into the wells. The reaction was stopped after 10 min with stopping buffer. The light absorbance at $492 \mathrm{~nm}$ was determined by a microplate reader (Labsystems, Shanghai, China). The kit was proved by the Chinese Food and Drug Administration for in vitro diagnostic use.

Statistical analyses were performed with the Statistical Program for Social Sciences (SPSS 13.0 for Windows, SPSS, Chicago, IL). Continuous variables were tested using the ttest. Statistical significance was denoted as a $P$ value less than 0.05 .

Of the 496 patients, $380(76.6 \%)$ had detectable serum HBV DNA by real-time PCR. The median HBV DNA level of these patients was $5.44 \log _{10}$ copies/ml (range 3.02 to 8.77 $\log _{10}$ copies $/ \mathrm{ml}$ ). Of the 380 patients with detectable HBV DNA, 276 patients (72.6\%) had precore G1896A mutation. Patients with precore mutations had significantly higher serum HBV DNA levels $\left(5.90 \pm 1.49 \log _{10}\right.$ copies/ml, Mean $\pm \mathrm{SD})$ than those with wild-type virus infection $(4.04 \pm 1.05$ $\log _{10}$ copies $\left./ \mathrm{ml}, P<0.01\right)$. Precore G1896A mutants were found in $248(83.8 \%)$ of 296 patients with $\mathrm{CHB}$, while only $28(33.3 \%)$ of 84 inactive HBV carriers with detectable HBV DNA had precore G1896A mutation (Table 2).

Table 2. Clinical parameters in patients with or without precore G1896A mutation

\begin{tabular}{lcc}
\hline & G1896A mutants & Wild-types $\boldsymbol{P}$ \\
\hline HBV DNA (Mean $\pm \mathrm{SD}, \log _{10}$ copies $\left./ \mathrm{mL}\right)$ & $5.90 \pm 1.49$ & $4.04 \pm 1.05<0.01$ \\
ALT (Mean $\pm \mathrm{SD}, \mathrm{IU} / \mathrm{L})$ & $91.6 \pm 67.3$ & $43.7 \pm 36.0<0.01$ \\
Chronic hepatitis (\%) & $248(83.8)$ & $48(16.2)$ \\
Inactive carriers (\%) & $28(33.3)$ & $56(66.7)$ \\
\hline
\end{tabular}


ALT levels in the serum of $\mathrm{HBsAg}$ positive, $\mathrm{HBeAg}$ negative, and HBV DNA detectable patients infected with the wild-type $\mathrm{HBV}$ was $43.7 \pm 36.0 \mathrm{IU} / \mathrm{L}$ (mean $\pm \mathrm{SD}$ ) compared with $91.6 \pm 67.3 \mathrm{IU} / \mathrm{L}$ in the serum of the patients with precore G1896A mutant HBV infection. The ALT levels in patients with detectable HBV DNA were significantly higher than that in HBV DNA undetectable carriers $(24.1 \pm 2.8$ IU/L, $P<0.01)$.

A total of $272(54.8 \%)$ patients were positive for pre-S1 antigen in serum. Serum pre-S1 antigen was detected in 248 (83.8\%) of the 296 patients with HBeAg-negative CHB compared with $24(12 \%, P<0.01)$ of 200 inactive carriers. Serum pre-S1 was found in 264 (69.5\%) of 380 patients with detectable HBV DNA. The mean HBV DNA level of pre-S1 antigen positive patients was significantly higher than that of pre-S1 antigen negative patients $\left(6.11 \pm 1.35 \log _{10}\right.$ copies $/ \mathrm{ml}$ vs $3.75 \pm 0.68 \log _{10}$ copies $\left./ \mathrm{ml}, P<0.01\right)$. Eight patients with positive pre-S1 antigen had undetectable HBV DNA. The mean ALT level of pre-S1 antigen positive patients was 67.6 $\pm 8.2 \mathrm{IU} / \mathrm{L}$, compared with $29.5 \pm 12.8 \mathrm{IU} / \mathrm{L}$ in pre-S1 negative patients $(P<0.01)$.

Of the 272 patients with serum positive pre-S1 antigen, $248(91.2 \%)$ had precore G1896A mutation. However, of the 224 patients with serum negative pre-S1 antigen, only 28 (12.5\%) had precore G1896A mutation. Of the 296 patients with $\mathrm{HBeAg}$ negative $\mathrm{CHB}$, serum pre-S1 antigen and precore G1896A mutation were simultaneously detected in $232(78.4 \%)$ patients. Among the 48 pre-S1 antigen negative patients with $\mathrm{HBeAg-negative} \mathrm{CHB}, 16$ (33.3\%) had precore G1896A mutation. Among the 200 inactive HBV carriers, $176(88 \%)$ were pre-S1 antigen negative (108 with undetectable HBV DNA, 56 with wild-type precore sequence, and 12 with precore G1896A mutation (Table 3).

Table 3. Relationship between precore G1896A mutation and pre-S1 antigen

\begin{tabular}{|c|c|c|c|c|c|c|c|}
\hline & \multicolumn{3}{|c|}{ Chronic hepatitis B $(n=296)$} & \multicolumn{4}{|c|}{ Inactive HBsAg carriers $(n=200)$} \\
\hline & G1896A & Wild-type & $\mathbf{R R}$ & G1896A & Wild-type & HBV DNA undetectable & $\mathbf{R R}$ \\
\hline Pre-S1 antigen positive & $232(93.5 \%)$ & $16(33.3 \%)$ & 2.81 & $16(57.1 \%)$ & $0(0 \%)$ & $8(6.9 \%)$ & 5.67 \\
\hline Pre-S1 antigen negative & $16(6.5 \%)$ & $32(66.7 \%)$ & & $12(42.9 \%)$ & $56(100 \%)$ & $108(93.1 \%)$ & \\
\hline
\end{tabular}

In the present study, we examined the prevalence of naturally occurring $\mathrm{HBV}$ precore G1896A mutation in Chinese patients with $\mathrm{HBeAg-negative} \mathrm{HBV}$ infection. We found that precore mutation can be frequently detected in Chinese patients with $\mathrm{HBeAg}$-negative $\mathrm{HBV}$ infection. In addition, the mutation is more often found in $\mathrm{HBeAg}$ negative patients with active CHB. Patients with precore G1896A mutation have significantly higher serum HBV DNA and ALT levels than those with wild-type virus infection. Moreover, serum pre-S1 antigen is more often detected in patients with precore G1896A mutation.
The influence of precore G1896A and basal core promoter mutations on the virulence of $\mathrm{HBV}$ infection remains controversial. The precore mutation may be associated with viral persistence in anti-HBe positive patients with ongoing chronic hepatitis B (11) and fulminant hepatitis $(2,5,9,24,33)$. Precore G1896A mutation was more frequent in patients with fulminant than acute self-limited hepatitis and was independently associated with the fulminant outcome (25). Jardi et al (16) reported that among HBeAg negative CHB, patients with precore G1896A mutation and elevated ALT showed highest HBV DNA, and simultaneous 
presence of the main $\mathrm{BCP}$ and precore mutations was associated with the degree of histological injury. The precore mutant correlated with high levels of HBV DNA in genotype D $\mathrm{HBeAg}$ negative $\mathrm{CHB}$, but its distribution was similar in $\mathrm{HBeAg}$ negative $\mathrm{CHB}$ patients and inactive carriers; thus it appears to have little value as a single marker for predicting disease activity (28). Other studies showed that the precore mutation has also been found in patients with inactive HBV carriers $(3,23)$, and not necessarily associated with progressive liver damage $(6,7,32)$. The percentage of the precore G1896A mutant in total virus is negatively associated with HBV DNA and ALT (26). Our results showed that precore G1896A mutation does exist in inactive HBV carriers with detectable serum HBV DNA. However, this mutation is more frequently found in patients with CHB than in inactive carriers $(83.8 \%$ vs $33.3 \%, P<0.01)$. Moreover, patients with precore mutation had much higher serum HBV DNA and ALT levels than patients without precore mutation $\left(5.90 \pm 1.49 \log _{10}\right.$ copies $/ \mathrm{ml} v s 4.04 \pm 1.05$ $\log _{10}$ copies/ml, $P<0.01$ and $91.6 \pm 67.3 \mathrm{IU} / \mathrm{L} v s 43.7 \pm 36.0$ IU/L, $\mathrm{P}<0.01$, respectively). This implies that precore mutant HBV still actively replicates in $\mathrm{HBeAg-negative}$ patients. The controversial results suggest that the role of precore mutation may be much more complex. Long-time follow-up studies are needed for further exploration of the role of precore mutations.

The prevalence of precore G1896A mutation varies geographically and depends on the genotypes of HBV (14). The G1896A mutation is found predominantly in HBV genotypes $\mathrm{B}, \mathrm{C}$, and $\mathrm{D}$, due to a genotype-specific nucleotide difference upstream from rt1896 that can critically alter the secondary conformation of the HBV encapsidation signal (27). The median prevalence of the G1896A mutation in HBeAg-negative patients is $50 \%$ in Asia, $92 \%$ in the Mediterranean, and 24\% in America (15). Our results showed that the overall prevalence of precore G1896A mutation in Chinese HBeAg-negative, serum HBV DNA detectable population was $72.6 \%$. The prevalence of G1896A mutation is significantly higher in $\mathrm{HBeAg-negative} \mathrm{patients} \mathrm{with} \mathrm{CHB}$ than in $\mathrm{HBeAg}$-negative inactive carriers. The relative risk (RR) of $\mathrm{CHB}$ in patients with precore mutation versus patients without precore mutation was 1.95 . These results may support the suggestion that the mutants are selected by immune pressure during $\mathrm{HBeAg}$ seroconversion, which is favorable to mutants with incapacitated $\mathrm{HBeAg}$ production (32).

Serum pre-S1 antigen levels are related to the degree of viral replication $(10,15)$. In the present study, we found that serum pre-S1 antigen was detected in $83.8 \%$ of $\mathrm{HBeAg}$ negative $\mathrm{CHB}$ patients but only $12 \%$ in inactive carries. Most patients with precore G1896A had detectable serum pre-S1 antigen. These results support the suggestion that precore G1896A mutation may lead to evade immune clearance of the virus. As a marker of $\mathrm{HBV}$ replication, serum pre-S1 antigen is not affected by the precore mutation. Thus serum pre-S1 antigen may be a potential indicator for active hepatitis in HBeAg-negative patiens. However, further studies are needed to determine the significance of serum pre$\mathrm{S} 1$ antigen for distinguishing $\mathrm{CHB}$ patients from inactive carriers.

In conclusion, the prevalence of precore G1896A mutation in $\mathrm{HBeAg-negative} \mathrm{CHB}$ patients is much higher than that in inactive HBV carriers. Serum pre-S1 antigen is detectable in most of the patients with the precore mutation.

\section{REFERENCES}

1. Ahn, S.H.; Kramvis, A.; Kawai, S.; Spangenberg, H.C.; Li, J.; Kimbi, G.; Kew, M.; Wands, J.; Tong, S. (2003). Sequence variation upstream of precore translation initiation codon reduce hepatitis $\mathrm{B}$ virus e antigen production. Gastroenterology, 125, 1370-1378.

2. Akahane, Y.; Yamanaka, T.; Suzuki, H.; Sugai, Y.; Tsuda, F.; Yotsumoto, S. (1990). Chronic active hepatitis with hepatitis B virus DNA and antibody against e antigen in the serum. Disterbed synthesis and secretion of e antigen from hepatocytes due to a point mutation in the precore region. Gastroenterology, 99, 1113-1119.

3. Akarca, U.S.; Greene, S.; Lok, A.S. (1994). Detection of precore hepatitis B virus mutants in asymptomatic $\mathrm{HBs} A g$-positive family members. Hepatology, 19, 1366-1370.

4. Ballard, A.L.; Boxall, E.H. (2000). Epidemiology of precore mutants of hepatitis B in the United Kingdom. J Med Virol, 62, 463-470. 
5. Carman, W.F.; Jacyna, M.R.; Hadziyannis, S.; Karayiannis, P.; McGarvey, M.J.; Makris, A. (1989). Mutation preventing formation of hepatitis B e antigen in patients with chronic hepatitis B infection. Lancet, II, 588-591.

6. Chan, H.L.; Hussain, M.; Lok, A.S. (1999). Different hepatitis B virus genotypes are associated with different mutations in the core promoter and precore regions during hepatitis $\mathrm{B}$ e antigen seroconversion. Hepatology, 29: 976-984.

7. Chan, H.L.; Leung, N.W.; Hussain, M.; Wong, M.L.; Lok, A.S. (2000). Hepatitis B e antigen-negative chronic hepatitis B in Hong Kong. Hepatology, 31: 763-768.

8. Chemin, I.; Baginski, I.; Petit, M.A.; Zoulim, F.; Pichoud, C.; Capel, F.; Hantz, O.; Trepo, C. (1991). Correlation between HBV DNA detection by polymerase chain reaction and pre-S1 antigenemia in symptomatic and asymptomatic hepatitis B virus infections. J Med Virol, 33, 51-57.

9. Ehata, T.; Omata, M.; Chuang, W.L.; Yokosuka, O.; Ito, Y.; Hosoda, K. (1993). Mutations in core mucleotide sequence of hepatitis B virus correlate with fulminant and severe hepatitis. J Clin Invest, 91, 12061213.

10. Escudero, M.D.; Quiroga, J.A.; Bartolome, F.J.; Carreno, V. (1991). Analysis of serum pre-S antigens in chronic hepatitis B virus infection in relation to the expression pattern of hepatitis B virus DNA in the liver. Digestion, 49, 204-211.

11. Grandjacques, C.; Pradat, P.; Stuyver, L.; Chevallier, M.; Cheballier, P.; Pichoud, C.; Maisonnas, M.; Trepo, C.; Zoulim, F. (2000). Rapid detection of genotypes and mutations in the pre-core promoter and the pre-core region of hepatitis $\mathrm{B}$ virus genome: correlation with viral persistence and disease severity. J Hepatol, 33, 430-439.

12. Hawkins, A.E.; Gilson, R.J.; Beath, S.V.; Boxall, E.H.; Kelly, D.A.; Tedder, R.S.; Weller, I.V. (1994). Novel application of a point mutation assay; evidence for transmission of hepatitis B viruses with precore mutations and their detection in infants with fulminant hepatitis B. $J$ Med Virol, 44, 13-21.

13. Hsu, Y.S.; Chien, R.N.; Yeh, C.T.; Sheen, I.S.; Chiou, H.Y.; Chu, C.M. (2002). Long-term outcome after spontaneous HBeAg seroconversion in patients with chronic hepatitis B. Hepatology, 35, 1522-1527.

14. Hunt, C.M.; McGill, J.M.; Allen, M.I.; Condreay, L.D. (2000). Clinical relevance of hepatitis B viral mutations. Hepatology, 31, 1037-1044.

15. Ibarra, M.Z.; Mora, I.; Bartolome, J.; Porres, J.C.; Carreno, V. (1989). Detection of proteins encoded by the pre-S region of hepatitis B virus in the sera of HBsAg carriers: relation to viral replication. Liver, 9, 153158.

16. Jardi, R.; Rodrigues, F.; Buti, M.; Costa, X.; Valdes, A.; Allende, H.; Schaper, M.; Galimany, R.; Esteban, R.; Guardia, J. (2004). Mutations in the basic core promoter region of hepatitis B virus. Relationship with precore variants and $\mathrm{HBV}$ genotypes in a Spanish population of $\mathrm{HBV}$ varriers. J Hepatol, 40, 507-514.

17. Karumu, S.; Arao, M.; Mizokami, M.; Orido, E.; Yamamoto, M.;
Sakamoto, N. (1989). Pre-S proteins in chronic hepatitis B virus infection: markers of active viral infection. Am J Gastroenterol, 84, 1250-1254.

18. Lee, W.M. (1997). Hepatitis B virus infection. $N$ Engl J Med, 337, $1733-1745$.

19. Lok, A.S.; Lai, C.L. (1990). Acute exacerbations in Chinese patients with chronic hepatitis B virus (HBV) infection. Incidence, predisposing factors and etiology. J Hepatol, 10, 29-34.

20. Lok, A.S. (2002). Chronic hepatitis B. N Engl J Med, 346, 1682-1683.

21. Lok, A.S.; McMahon, B.J. (2007). AASLD practice guidelines: Chronic hepatitis B. Hepatology, 45, 507-539.

22. Milich, D.; Liang, T.J. (2003). Exploring the biological basis of hepatitis B e antigen in hepatitis B virus infection. Hepatology, 38, 1075-1086.

23. Okamoto, H.; Tsuda, F.; Akahane, Y.; Sugai, Y.; Yoshiba, M.; Moriyama, K. (1994). Hepatitis B virus with mutations in the core promoter for an e antigen-negative phenotype in carriers with antibody to e antigen. $J$ Virol, $68,8102-8110$.

24. Omata, M.; Ehata, T.; Yokosuka, O.; Hosoda, K.; Ohto, M. (1991). Mutations in the precore region of hepatitis B virus DNA in patients with fulminant and severe hepatitis. NEng J Med, 324, 1699-1704.

25. Ozasa, A.; Tanaka, Y.; Orito, E.; Sugiyama, M.; Kang, J.H.; Hige, S.; Kuramitsu, T.; Suzuki, K.; Tanaka, E.; Okada, S.; Tokita, H.; Asahina, Y.; Inoue, K.; Kakumu, S.; Okanoue, T.; Murawaki, Y.; Hino, K.; Onji, M.; Yatsuhashi, H.; Sakugawa, H.; Miyakawa, Y.; Ueda, R.; Mizokami, M. (2006). Influence of genotypes and precore mutations on fulminant or chronic outcome of acute hepatitis B virus infection. Hepatology, 44, 326-334.

26. Pang, A.; Yuen, M.F.; Yuan, H.J.; Lai, C.L.; Kwong, Y.L. (2004) Real-time quantification of hepatitis $\mathrm{B}$ virus core-promoter and precore mutants during hepatitis E antigen seroconversion. $J$ Hepatol, 40, 1008-1017.

27. Rodriguez-Frias, F.; Buti, M.; Jardi, R.; Cotrina, M.; Viladomiu, L.; Esteban, R.; Guardia, J. (1995). Hepatitis B virus infection: precore mutants and its relation to viral genotypes and core mutations. Hepatology, 22, 1641-1647.

28. Rodriguez-Frias, F.; Jardi, R.; Buti, M.; Schaper, M.; Hermosilla, E.; Valdes, A.; Allende, H.; Martell, M.; Esteban R.; Guardia, J. (2006). Hepatitis B virus genotypes and G1896A precore mutation in 486 Spanish patients with acute and chronic HBV infection. $J$ Viral Hepat, 13, 343-350.

29. The Incident Investigation Teams and others (1997). Transmission of hepatitis B to patients from four infected surgeons without hepatitis B e antigen. $N$ Engl J Med, 336, 178-184.

30. Theilmann, L.; Klinkert, M. Q.; Gmelin, K.; Salfeld, J.; Schaller, H.; Pfaff, E. (1986). Detection of pre-S1 proteins in serum and liver of HBsAg-positive patients: a new marker for hepatitis B virus infection. Hepatology, 6, 186-190. 
31. Waltz, T.L.; Marras, S.; Rochford, G.; Nolan, J.; Lee, E.; Melegari, M.; Pollack, H. (2005). Development of a molecular-beacon assay to detect the G1896A precore mutation in hepatitis B virus-infected individuals. J Clin Microbiol, 43, 254-258.

32. Yoo, B.C.; Park, J.W.; Kim, H.J.; Lee, D.H.; Cha, Y.J.; Park, S.M. (2003). Pre-core and core promoter mutations of hepatitis B virus and hepatitis B e antigen-negative chronic hepatitis B in Korea. J Hepatol, 38, 98-103.

33. Yotsuyanagi, H.; Hino, K.; Toyoda, J.; Yasuda, K.; Ino, S. (2002). Precore and core premoter mutations, hepatitis B virus DNA levels and progressive liver injury in chronic hepatitis B. J Hepatol, 37, 355-363. 